УДК 65.011.56:007.52

\title{
SECURITY ROBOTIC INDUSTRIAL PROCESSES
}

\author{
Aldona Kuśmińska-Fijałkowska, PhD, A. Mastepan
}

БЕЗПЕКА РОБОТИЗОВАНИХ ВИРОБНИЧИХ ПРОЦЕСІВ

Алдона Кузмінська-Фіалковська, доктор філософії, А.Г. Мастепан

\section{БЕЗОПАСНОСТЬ РОБОТИЗИРОВАННЫХ ПРОИЗВОДСТВЕННЫХ ПРОЦЕССОВ}

\section{Алдона Кузминская-Фиалковская, доктор философии, А.Г. Мастепан}

В даний час спостерігається тенденція зростання числа автоматизованих $i$ роботизованих виробничих прочесів на машинобудівних підприємствах та підприємствах обслуговування та ремонту залізничної техніки. Відповідно до даної тенденцією виникає потреба в розробизі та аналізі вимог безпеки, щчо пред'являються до машини. У роботі проаналізовано найважливіші етапи життєвого циклу роботів і ризики, щэо виникають за цей час, ие необхідно для подальшої розробки стандартів пов'язаних з безпечною роботою машин на виробництві.

Ключові слова: безпека, робот, мачина.

В данное время наблюдается тендениия роста числа автоматизированных $и$ роботизированных производственных прочессов на машиностроительных предприятиях $u$ предприятиях обслуживания и ремонта железнодорожной техники. В соответствии $c$ данной тенденцией возникает потребность в разработке и анализе требований безопасности, предъявляемых к машине. В работе проанализированы важнейшие этапь жизненного ичкла роботов и риски, возникающие за это время, это необходимо для дальнейшей разработки стандартов связанных с безопасной работой машин на производстве.

Ключевые слова: безопасность, робот, машина. 
Now there is a tendency of increasing the number of automated and robotic manufacturing processes at the machine-building enterprises and the enterprises of maintenance and repair of railway equipment.

In accordance with this tendency there is a need in development and analysis of safety requirements to the machine. This work analyzes the most important stages of the life cycle of the robots and the risks that occurring during this period, it is necessary for the further development of standards related to the safe operation of machinery at work.

In the European Union producers, distributors and users of all industrial facilities must follow the instructions of the Machinery Directive. The Directive recognizes exactly that machines can not be a source of danger for those working in the industry. Unfortunately, there is no technology without risks, because the aim should be to achieve an acceptable risk

Keywords: safety, robot, machine.

\section{Introduction.}

In automated production processes, there are risks that can lead to damage to property or cause an accident. [7,10] GUS distinguishes the following types of threats:

- The risk factors associated with the work environment: among them were the most harmful chemicals, industrial dusts and noise;

- Risks associated with strenuous work, for example. Forced posture, heavy exercise, insufficient illumination jobs, etc.;

- The harmful effects of mechanical factors associated with particularly dangerous machinery (such as circular saws and belt, milling machines, presses and other).

Industrial robots are a means to eliminate such hazards. [5, 6] The primary function of robots to replace humans in the work difficult and dangerous.[8, 12] Another important factor in dissemination of robotics and more important as time goes on the cost-effectiveness of this process automation, resulting from the improvement, product quality and better use of the means of production.[9] Unfortunately, industrial robot may also cause danger. Therefore it is necessary to use appropriate preventive measures.[13]

\section{process.}

Safety of machinery in the production

Safety in robotic manufacturing processes is a concept involving the protection of human life and health, as well as production machines, transport, energy and others. It also has all the problems related to the continuity of production. [11] The most unreliable part of the production process is the man operator or technician who ork. The foundation of safe operation of the robot are primarily regularly reviewed and neglects their duties, which neglects the duties. Therefore, every human contact with the robot should be considered as a potential source of danger. The consequences of accidents are a threat to health or life of employees as well as material losses incurred by the company. Therefore, the responsibility for the safety of in the workplace lies not only users of industrial robots, but also designers, manufacturers and suppliers of machinery. Ensure the safety of the process line forcing provisions of the European Union and the Polish standards. Machinery Directive standards are constantly updated, so you should keep track of the changes. [2]

The legal standard governing the safety of machinery applies to all devices involved in the production process. The European Union has introduced two pillars of safety for new machines (for the first time entering the European Union) and equipment already in use.

The design of the new devices should provide security at a certain high level. Machines used should be adjusted and maintained at a minimal level, which would ensure safety (Fig. 1).

\section{Secure the robot.}

Guidance on the safe operation of the robot can be found in the harmonized standard EN ISO 10218-1 and ISO 10218-2. These standards describe the basic threats and situations jeopardizing the safety of robotic industrial applications. Also specified requirements to eliminate or reduce the risks associated with those hazards. Current regulations of 2011 also include the security of the entire system w

its proper maintenance. Working production machine performs ultra fast movements, which 
is why it is important to secure an area in its range. For this purpose, the most commonly used security fence and other collateral, such as light curtains, safety locks sensor, pressure mats, warning lights, buttons, safety, mechanical stops, which will write in later chapters.

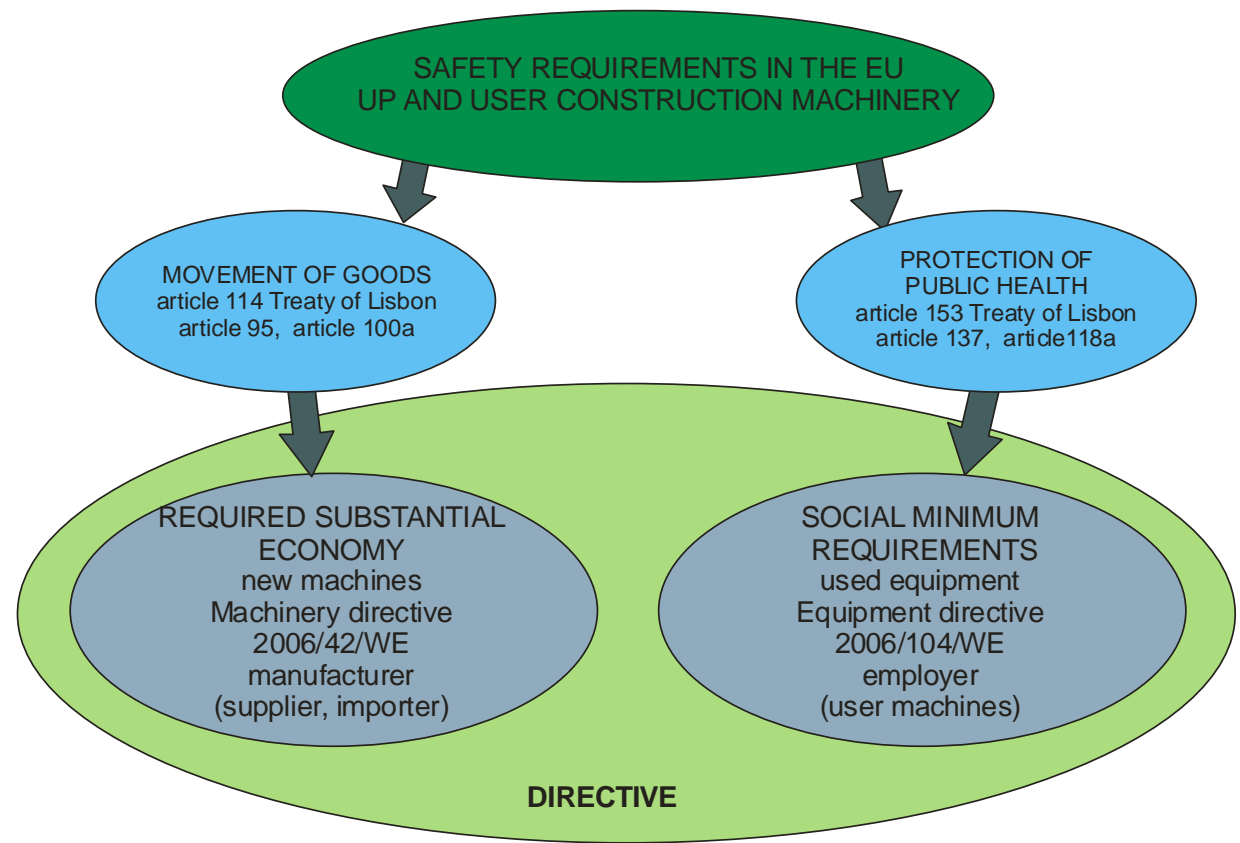

Fig. 1. EU regulations relating to new and used robots

$<250 \quad \mathrm{~mm} \quad / \quad \mathrm{s}$.

In order to avoid an accident while working with the robot, it is essential to follow certain rules:

- operators of industrial robots and robotized whole can only be persons who have received appropriate training;

- forbidden to reside within the area of the robot during automatic operation and during testing at high speeds;

- prohibits the bridge safety sensors and security systems (bypassing security systems, in which the machine is provided);

- in the case of imminent danger to health or life should immediately use a safety button (red mushroom);

- prohibits the robot attempts to stop his own body (in order to quickly stop the robot use the buttons safety);

- prohibits the closing of others in the field of the robot;

- Before entering the robot work area must stop execution of the program, robot switch to manual mode with a speed limit

\section{Design of robotic industrial process.}

The basic principles of designing a safe position robotic and other equipment used in processing determines the standard BS EN ISO 12100. It defines the key terms are set out the next steps and principles of assessment and risk reduction. The standard is to facilitate the designers to ensure the safety of equipment at the design stage. The next steps of the risk assessment should be:

- identify the limits of the machine including the life of the machine as intended and foreseeable use of the wrong;

- identification of hazards and situations associated with them;

- risk assessment for each hazardous situation;

- decide if you need to reduce risk.

The risk assessment is based on a systematic gathering of information and analysis of the potential hazard to the line. After the risk assessment, if necessary, use protective measures - reducing the risk. Protective 
measures are solutions used by the designer and the user. Their goal is to increase security. It is recommended to use the solutions proposed by the designer, since the protective measures selected by the user are usually less effective (Fig. ).

The first protective measures, which should offer designer design solutions, are secure in themselves. Risk reduction through the use of these measures is to take the geometric factors and physical aspects of machine:

- machine components should be designed in such a way as to allow observation of the working areas and danger zones;

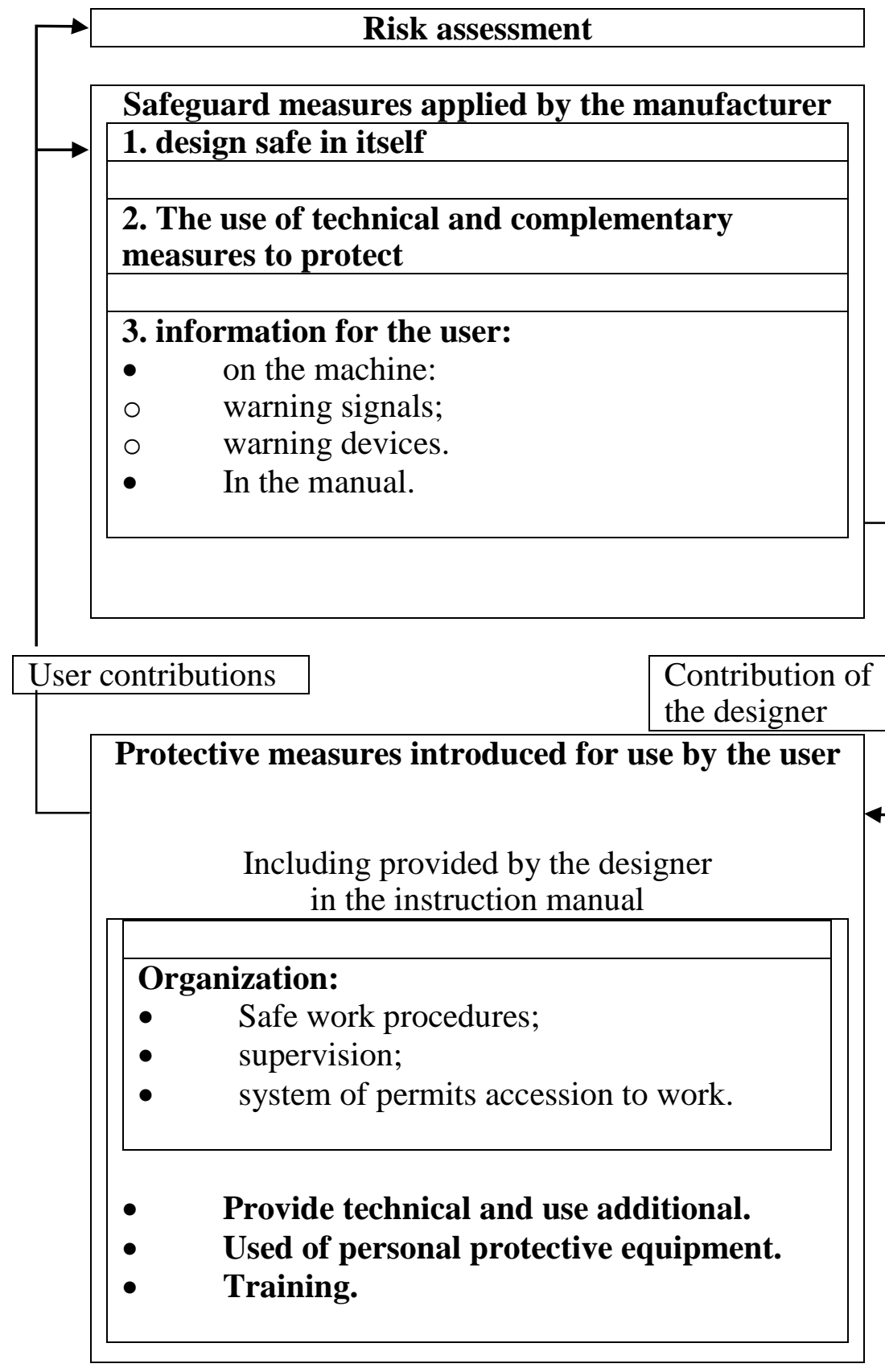

- avoid the use of any sharp edges and protruding;

- maximize the distance of the moving parts of the machine operator, so that it was possible to maintain a safe distance;

- allow the operator easy access to control elements;

- limiting the force needed to run;

- reducing the weight or speed of moving parts;
The residual

risk after

applying all

protective

measures by

the designer.

The residual risk after applying all protective measures

Fig. 2. Reducing the risk of a design standpoint [4] 
If the design solutions in themselves do not reduce the threat to the required level, use technical conservation measures (guards, electro-sensitive device) and additional protective measures (emergency stop equipment). Designers should be aware that it is necessary to provide the user with information about the device correct operation. Such documentation should include information on the hazards of the machine and to define the measures which should be taken to eliminate them. Depending on the emergency, you must decide what warnings are sufficient (the information in the documentation, warning signs). If using these signals and warning devices must be unambiguous and issued prior to the incident. [4]

Analysis of the risks of robotic industrial process.

At the moment of conception of a new industrial robot in the first place should refer to the archived data. If in the past created a similar device it is possible to know the problems they grappled the user. Unfortunately, you can not always learn from others' mistakes and experiences. Therefore, you should analyze the risks and dangers of the project.

Elimination of hazards at the design stage of an industrial installation is important at every stage of the life of the device. General issues relating to the safety of the production plant is called process safety. [2]

Process safety department relating to the controlled equipment (EUC - equipment under control) and the control system is functional safety. It is a branch of engineering which includes issues of risk prevention by designing precise functions operating in hazardous conditions. Each phase of life industrial applications require the use of appropriate methods of analysis (Fig. 3.)

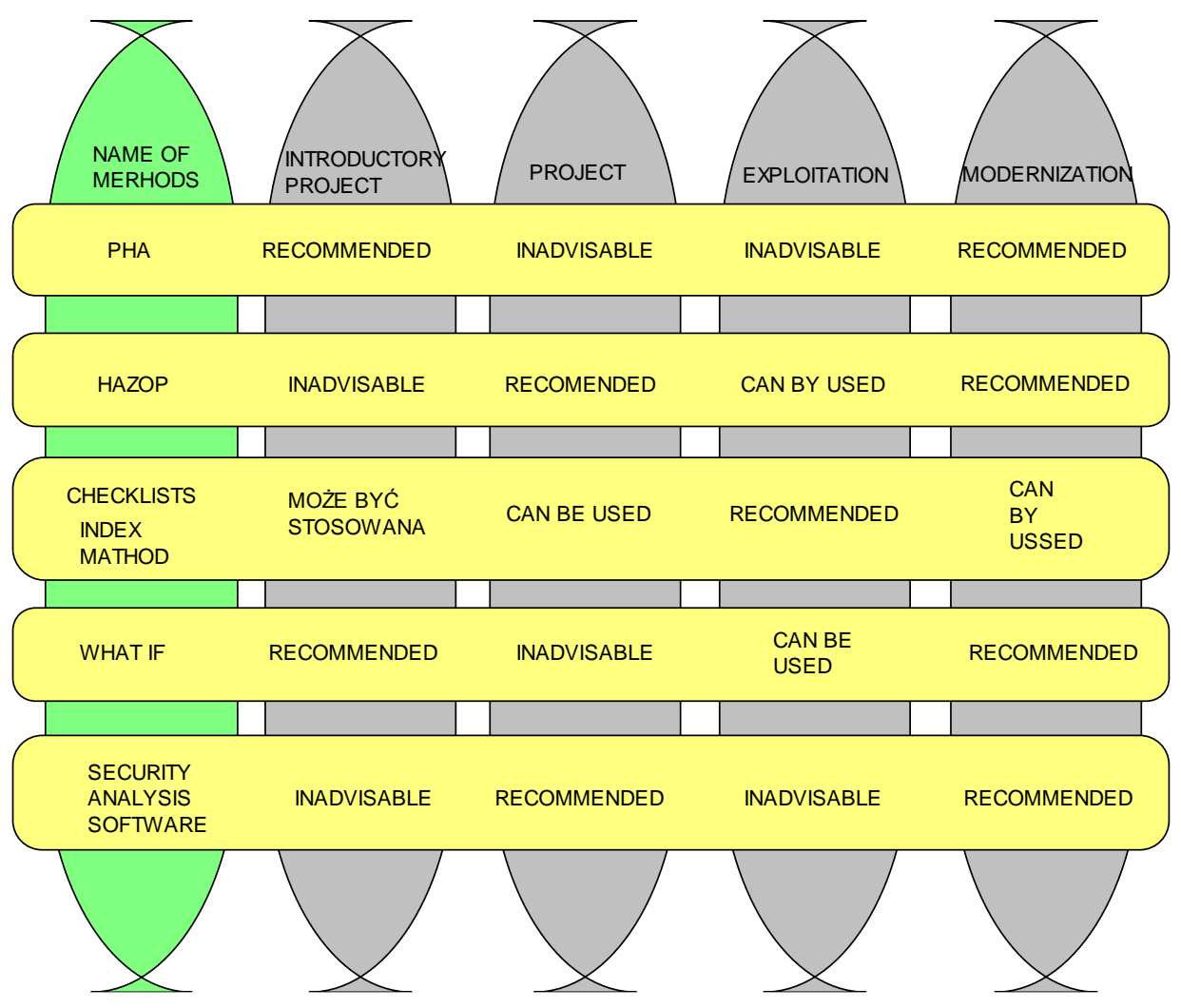

Fig. 3 The use of safety analysis methods

In engineering practice, are used in the methods summarized below [2]:
- comparative method (applied knowledge of similar installations): 
Index);

oindex method (e.g. DOW Index, OPS

oof checklists threats):

-inspection method (systematic review of

oPHA (Preliminary Hazard Analysis); Study);

○HAZOP (Hazard and Operability

o,What - If"

- analytical methods (detection and quantitative assessment of the risks of accident scenarios):

oFMEA (Fault Mode and Effect Analysis);

oFTA (Fault Tree Analysis);

oETA (Event Tree Analysis);

oCCA (Cause Consequence Analysis).

\section{Conclusions.}

The creation of a growing number of industrial robots and their continuous development pose problems of cooperation between man and machine. Threat to the machine operators is the increasing rate of production equipment. Technological advances mean that a person becomes less suitable to work in the factory. Industrial robots are able to perform complex tasks in a short period of time, as this is more reliable. Unfortunately, the current technology is not able to replace humans in every position on the line. Even so advanced devices such as industrial robots require the presence of the operator. The increasing number of automated processes and care about the safety of the workers were impetus to the requirements to be met by the machine. In the European Union producers, distributors and users of all industrial facilities must follow the instructions of the Machinery Directive. The Directive recognizes exactly that machines can not be a source of danger for those working in the industry. Unfortunately, there is no technology without risks, because the aim should be to achieve an acceptable risk

\section{Bibliography}

1. Łabanowski, W. Safety in use of machinery [Text] / W. Łabanowski. - Warsaw, 2012.

2. Human Safety of machinery processes the monthly allowance 2011. Engineering and maintenance. - Warsaw: Trade Media, 2011.

3. PN-EN ISO 10218: 2011. Construction and equipment for robotics - Safety requirements for industrial robots. reduction.

4. PN-EN ISO 12100: 2012. General principles for design - Risk assessment and risk

5. Kuśmińska-Fijałkowska, A. Programming trajectory industrial robot palletizing process [Text] / A. Kuśmińska-Fijałkowska, Z. Lukasik. - Journal of Logistics 3/2014. - pp. 3577-3582, ISSN 1231-5478.

6. Łukasik, Z. Critical Infrastructure Security Management [Text] / Z. Łukasik, W. Nowakowski, A. Kuśmińska-Fijałkowska. - Journal of Logistics 4/2014. - CD1, pp. 758-763, ISSN 1231-5478.

7. Kozyra, J. Linear elements used in securing logistics facilities explosive [Text] / J. Kozyra, A. Kuśmińska-Fijałkowska. - Journal of Logistics 4/2014. - CD1, pp. 572-580, ISSN 1231-5478.

8. Kuśmińska- Fijałkowska A., Łukasik Z.: "" Robotic laboratory system based on robot Fanuc S-420F ". 14 International Conference "TransComp", Zakopane 6-9. ISBN 978-83-7204956-8, 12. 2010, Logistics 6/2010

9. Kuśmińska-Fijałkowska, A. Programming KAREL industrial robot Fanuc S-420F. Structuring the program - Procedures [Text] / A. Kuśmińska-Fijałkowska, Z. Łukasik. - Journal of Railway Transport Technology 9/2012. - ISSN 1232-3829.

10. Krajewska, R. The design of storage systems [Text] / R. Krajewska, Z.Łukasik. - Journal of Logistics 6/2009.

11. Krajewska, R. Managing logistics projects in the power plant [Text] / R. Krajewska, Z. Łukasik. - Journal of Logistics 3/2014. - pp. 3236-3246, ISSN 1231-5478. 
12. Krzyszkowski, A. Logistics and Security asymmetric [Text] / A. Krzyszkowski, Journal of Logistics 3/2014.

13. Bril, J. Transport safety [Text] / J. Bril, Z. Łukasik. - Journal of Buses, Engineering, Operation, Transport Systems 3/2013. - pp. 1895-1905, ISSN 1509-5878.

Aldona Kuśmińska-Fijałkowska, PhD, University of Technology and Humanities, Faculty of Transport and Electrical Engineering, Poland

Anton Mastepan, assistant, Department of automated systems of electric transport, Ukrainian State Academy of Railway Transport, Contact tel .: (057) 730-10-76, E-mail: antonua86@bk.ru

Алдона Кузмінська-Фіалковська, доктор філософії, Університет технологій та гуманітарних наук, Факультет транспорту та електротехніка, Польща

Мастепан Антон Геннадійович, Асистент, Кафедра автоматизованих систем електричного транспорту, Українська державна академія залізничного транспорту, Контактний тел.: (057) 730-10-76, E-mail: antonua86@bk.ru

Стаття поступила 20.05.2015 